Check for updates

Cite this: RSC Adv., 2019, 9, 20058

\title{
Design and synthesis of supramolecular functional monomers bearing urea and norbornene motifs $\dagger$
}

\author{
Lulu Wang, ${ }^{\text {abc }}$ Qifeng Lin, ${ }^{d}$ Yagang Zhang, (D) *abc Yanxia Liu, ${ }^{\text {abc }}$ Akram Yasin ${ }^{b}$ \\ and Letao Zhang ${ }^{\mathrm{b}}$
}

Three sets of functional monomers namely urea-based, 2-ureido-4[1H]-primidone (UPy)-based and norbornene based functional monomers were designed and synthesized. These functional monomers (FM) were obtained in decent yields using amine and isocyanate/norbornene as starting materials. Methacrylate and styrene isocyanate with 1,4-diaminobutane/tris(2-aminoethyl)amine were chosen for the synthesis of symmetrical, asymmetrical and three-branched urea-functional monomers, respectively. UPy-based FMs were synthesized with isocyanate and 2-amino-4-hydroxy-6-methylpyrimidine. The synthesis of these monomers feature short reaction times, mild reaction conditions and no need for column chromatographic purification. Furthermore, the norbornene based FM was used for preparing molecularly imprinted polymers (MIPs) by Ring-Opening Metathesis Polymerization (ROMP). Results showed that these synthetic routes represent a convenient and useful approach for synthesis of novel functional monomers.

Received 11th March 2019

Accepted 21st June 2019

DOI: $10.1039 / c 9 r a 01852 b$

rsc.li/rsc-advances imprinting. ${ }^{7}$ The study indicated that the aggregation of functional monomers could help reduce the number of background sites. Specifically, the urea-based monomers were found to form linear hydrogen bonded aggregates and could significantly reduce the number of background sites in molecularly imprinted polymers. ${ }^{8-14}$

The design and synthesis of molecular imprinting polymers for biomolecules and its optimization is important yet very challenging. ${ }^{15,16}$

It is practically important to design and synthesize new functional monomers capable of forming strong interactions with templates featuring high affinity and specificity. Generally, an ideal functional monomer would combine at least two types of functionality: a polymerizable vinyl group; a suitable functional group that could interact strongly with the template. What's more, appropriate adaptive cross-linkers are also needed to form pre-polymerization complex in order to form rigidly fixed polymer matrix and to improve imprinting fidelity.

Along this line, in the work reported here, three sets of functional monomers specifically urea-based, UPy(2-ureido-4 $[1 \mathrm{H}]$-pyrimidinone)-based and multi-arm urea and norbornene based functional monomers were designed and synthesized. And the multi-arm norbornene based functional monomers were used for preparing MIPs via ring-opening metathesis polymerization.

Results showed that these synthetic routes represent a convenient and practical strategy for synthesis of functional monomers. While norbornene based multi-arm functional monomers could be used for preparing MIPs for free radical quencher type template molecules.

\footnotetext{
Department of Chemical and Environmental Engineering, Xinjiang Institute of 3838957; Tel: $+86-18129307169$

${ }^{b}$ Xinjiang Technical Institute of Physics and Chemistry, Chinese Academy of Sciences, Urumqi 830011, China

${ }^{c}$ University of Chinese Academy of Sciences, Beijing 100049, China

${ }^{d}$ Xinjiang Institute of Ecology and Geography, Chinese Academy of Sciences, Urumqi, Xinjiang 830011, China

$\dagger$ Electronic supplementary information (ESI) available. See DOI: 10.1039/c9ra01852b
} 


\section{Results and discussion}

\subsection{Synthesis of functional monomers}

The synthesis of urea-based functional monomer started out using 1,4-diaminobutane and commercially available isocyanate as a precursor to form the urea unit (Table 1). Results showed that symmetrical functional monomer was formed when $\mathrm{CH}_{2} \mathrm{Cl}_{2}$ was used as solvent at room temperature for $4 \mathrm{~h}$ (Table 1 , entry 1 ).

Next, reducing reaction temperature to $0{ }^{\circ} \mathrm{C}$ gave $2 \mathrm{a}$ in $10 \%$ and $2 \mathrm{c}$ in $34 \%$ yields, respectively. With reaction time $2 \mathrm{~h}$ at $\mathrm{rt}$, the yield of $2 \mathrm{a}$ was improved to $42 \%$ and $2 \mathrm{c}$ was decreased to $12 \%$ (Table 1, entries 2 and 3). Results indicated that reaction time and temperature strongly influenced the resulting products. Based on above observations, we further explored other solvents. 1,4-Diaminobutane was slowly added dropwise into a solution of isocyanate at $0{ }^{\circ} \mathrm{C}$ using various different solvent including THF, DMF and toluene, giving only trace amount of product or no reaction (Table 1, entries 4-6). Noticeably, when using $\mathrm{CH}_{3} \mathrm{CN}$ as solvent, the yield of $2 \mathrm{a}$ increased to $68 \%$. And the yield did not change significantly when the reaction was carried out at $-20{ }^{\circ} \mathrm{C}$.

With the optimized conditions in hand, the scope of the urea unit synthesis was further expanded and explored (Table 1, entries 9 and 10). It was found the reaction of urea-unit FM with 1,4-diaminobutane substrate bearing different functional groups such as styrene and methacrylic acid ester in $\mathrm{CH}_{2} \mathrm{Cl}_{2}$ or $\mathrm{CH}_{3} \mathrm{CN}$ gave the symmetrical urea-functional monomers in

Table 1 Synthesis of urea based functional monomers

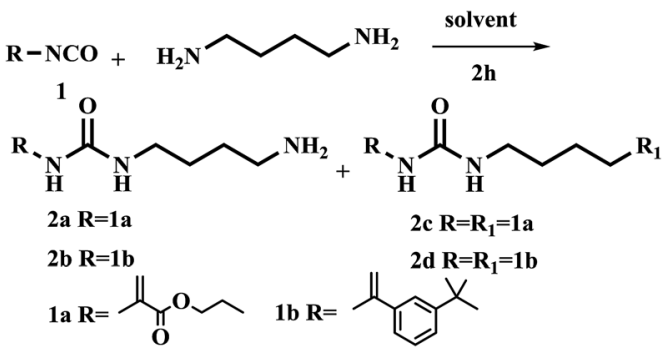

\begin{tabular}{llllll}
\hline Entry & R-NCO (equiv.) & Solvent & $T\left({ }^{\circ} \mathrm{C}\right)$ & Time (h) & Product (yield) \\
\hline 1 & $\mathbf{1 a}(1.1)$ & $\mathrm{CH}_{2} \mathrm{Cl}_{2}$ & $\mathrm{rt}$ & $4 \mathrm{~h}$ & $\mathbf{2 c}(43.6 \%)$ \\
2 & $\mathbf{1 a}(1.1)$ & $\mathrm{CH}_{2} \mathrm{Cl}_{2}$ & 0 & $4 \mathrm{~h}$ & $\begin{array}{l}\mathbf{2 a}(10.2 \%) \\
\mathbf{2 c}(32.4 \%)\end{array}$ \\
& & & & & $\mathbf{2 a}(42.3 \%)$ \\
3 & $\mathbf{1 a}(1.1)$ & $\mathrm{CH}_{2} \mathrm{Cl}_{2}$ & 0 & $2 \mathrm{~h}$ & $\mathbf{2 c}(12.0 \%)$ \\
4 & $\mathbf{1 a}(1.1)$ & $\mathrm{THF}$ & 0 & $2 \mathrm{~h}$ & $\mathbf{2 a}$ (trace) \\
5 & $\mathbf{1 a}(1.1)$ & $\mathrm{DMF}$ & 0 & $2 \mathrm{~h}$ & $\mathbf{2 a}$ (trace) \\
6 & $\mathbf{1 a}(1.1)$ & $\mathrm{PhCH}_{3}$ & 0 & $2 \mathrm{~h}$ & $\mathbf{2 a}($ trace) \\
7 & $\mathbf{1 a}(1.1)$ & $\mathrm{CH}_{3} \mathrm{CN}$ & 0 & $2 \mathrm{~h}$ & $\mathbf{2 a}(68.4 \%)$ \\
8 & $\mathbf{1 a}(1.1)$ & $\mathrm{CH}_{3} \mathrm{CN}$ & -20 & $2 \mathrm{~h}$ & $\mathbf{2 a}(65.1 \%)$ \\
9 & $\mathbf{1 a}(2.1)$ & $\mathrm{CH}_{2} \mathrm{Cl} 2$ & $\mathrm{rt}$ & $2 \mathrm{~h}$ & $\mathbf{2 c}(99.8 \%)$ \\
10 & $\mathbf{1 b}(1.1)$ & $\mathrm{CH}_{3} \mathrm{CN}$ & 0 & $2 \mathrm{~h}$ & $\mathbf{2 b}(78.8 \%)$ \\
11 & $\mathbf{1 b}(2.1)$ & $\mathrm{CH}_{2} \mathrm{Cl}_{2}$ & $\mathrm{rt}$ & $2 \mathrm{~h}$ & $\mathbf{2 d}(96.7 \%)$
\end{tabular}

${ }^{a}$ Reaction condition: 1,4-diaminobutane $(1 \mathrm{mmol})$, isocyanate (1.1 $\mathrm{mmol} / 2.1 \mathrm{mmol})$ in the indicated solvent $(10 \mathrm{~mL})$ at $0{ }^{\circ} \mathrm{C}(\mathrm{rt})$. decent to excellent yield (entries 9 and 10). 2c compound was synthesized according to procedure reported by Schmitzer with $50 \%$ yield. ${ }^{17}$ In the procedure reported here, $2 \mathrm{c}$ was obtained in $99 \%$ yield.

The 2-ureido-4[1H]-pyrimidone (UPy) unit has been used as a building block for quadruple hydrogen bonding. Theoretically, its hydrogen-bonding ability could play a crucial role in the function and structure of polymerizable monomers. ${ }^{\mathbf{1 8 - 2 0}}$ Thus, 2-amino-4-hydroxy-6-methylpyrimidine was chosen as the model substrate for the optimization of reaction conditions (Table 2). The influence of time, reaction temperature and the solvent nature were investigated. Firstly two isocyanatoethyl methacrylates and different solvents were tested. It was found that the yields of the reaction were relatively low without any solvent (Table 2, entries 1 and 2). When pyridine was used as solvent, the yield of 3 a was improved to $85.4 \%$ (Table 2, entry 3 ). The reaction was also carried out in DMSO (Table 2, entries 58). Compound 3a was obtained in good yield when 1.1 or 1.3 equiv. UPy substrate was used at $170{ }^{\circ} \mathrm{C}$ in less than 5 min under optimized conditions for compound $3 \mathbf{a}$ (Table 2, entry 8 ) and for compound 3b (Table 2, entry 9).

An important feature of multi-valent monomers was that they have multiple flexible "arms" which can wrap around the template molecule so to render higher affinity and selectivity than traditional MIPs based on mono-valent FMs. ${ }^{21}$ Shimizu ${ }^{22,23}$ et al. synthesized the methacrylic acid ester type three-armed functional monomer bearing urea functionality as phosphate receptor to increase the affinity and imprinting efficiency. In the work reported here, both methacrylate and styrene type precursors were used for the synthesis of FMs. The advantage of aryl groups linked to the urea motifs commonly increases the receptor's affinity toward anionic template. ${ }^{24}$ Along this line, three-branched monomer 4 was designed and obtained in 90\%

Table 2 Synthesis of UPy-based functional monomers

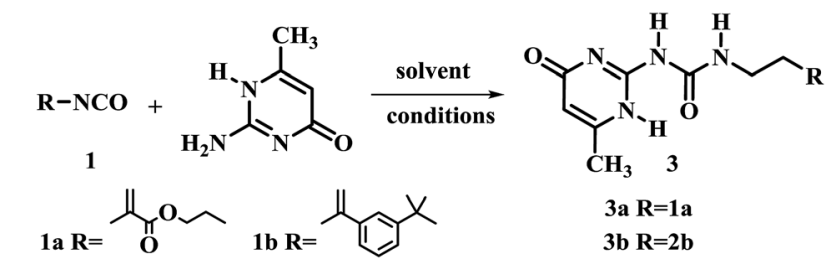

\begin{tabular}{llllll} 
Entry & R-NCO (equiv.) & Solvent & $T\left({ }^{\circ} \mathrm{C}\right)$ & Time (h) & Product (yield) \\
\hline 1 & 1a $(2)$ & Neat & 100 & $21 \mathrm{~h}$ & $\mathbf{3 a}(53.1 \%)$ \\
2 & $\mathbf{1 a}(3)$ & Neat & 100 & $21 \mathrm{~h}$ & $\mathbf{3 a}(60.7 \%)$ \\
3 & $\mathbf{1 a}(3)$ & Pyridine & 100 & $16 \mathrm{~h}$ & $\mathbf{3 a}(85.4 \%)$ \\
4 & $\mathbf{1 a}(3)$ & Pyridine & 100 & $8 \mathrm{~h}$ & $\mathbf{3 a}(83.9 \%)$ \\
5 & $\mathbf{1 a}(1.1)$ & DMSO & 120 & $2 \mathrm{~h}$ & $\mathbf{3 a}(86.4 \%)$ \\
6 & $\mathbf{1 a}(1.3)$ & DMSO & 120 & $2 \mathrm{~h}$ & $\mathbf{3 a}(87.0 \%)$ \\
7 & $\mathbf{1 a}(1.3)$ & DMSO & 140 & $20 \mathrm{~min}$ & $\mathbf{3 a}(86.5 \%)$ \\
8 & $\mathbf{1 a}(1.3)$ & DMSO & 170 & $5 \mathrm{~min}$ & $\mathbf{3 a}(87.6 \%)$ \\
9 & $\mathbf{1 b}(1.3)$ & DMSO & 170 & $5 \mathrm{~min}$ & $\mathbf{3 b}(89.6 \%)$
\end{tabular}

${ }^{a}$ Reaction condition: isocyanate (1 mmol), 2-amino-4-hydroxy-6methylpyrimidine $(1.1-3 \mathrm{mmol})$ in the indicated solvent (neat/6 $\mathrm{mL}$ ) at $100{ }^{\circ} \mathrm{C}\left(170^{\circ} \mathrm{C}\right)$. Yield of recrystallization. 
yield by reacting tris(2-aminoethyl)amine with 3-isopropenyl$\alpha, \alpha$-dimethylbenzyl isocyanate $(\mathbf{1 b})$ in $\mathrm{CH}_{2} \mathrm{Cl}_{2}$ at room temperature for $6 \mathrm{~h}$ (Scheme 1).

The monomer 5 is noteworthy because it can be used as both functional monomer and cross linker. In this synthesis, cis-5norbornene-endo-2,3-dicarboxylic anhydride was chosen as starting material. The advantages of monomer 5 include (1) basic nitrogen centered three armed structure could interact strongly with the template (2) three norbornene imide with stringed bridge double bond could participate in ring opening metathesis polymerization (ROMP) reactions and to improve the degree of crosslinking. ${ }^{25}$ More importantly, monomer 5 provides a possibility for preparing MIPs for free radical quencher type template molecules which is usually difficult to work with free radical type polymerization approach.

\subsection{Synthesis of BHA/BHT-MIPs and NIPs}

Generally, MIPs could be prepared with free-radical polymerization and sol-gel processes. Bulk polymerization with freeradical initiator is one of the most popular approaches which possess many attractive advantages. ${ }^{26,27}$ However, preparation of MIP for free radical quencher type template is not easy in conventional radical polymerization. For example, the amount of initiator needed was doubled for gossypol as template. ${ }^{28}$ Since the free radical quencher type template could block the radical initiation and propagation process. The ROMP using ruthenium-based Grubbs catalysts have was found highly desirable for various substituted cyclic olefins such as norbornenes. ${ }^{29,30}$ We envisioned that this approach could be useful to synthesize MIPs for free radical quencher type template molecules which is hard to be prepared with free radical type polymerization approach (Fig. 1).

Butylated hydroxyanisole (BHA) and 2,6-di-tert-butyl-4methylphenol (BHT) as classified antioxidants, has been widely used in food and pharmaceutical. However, when the total content of antioxidants are more than $0.02 \mathrm{wt} \%$ of the total fat/oil content of the food, it is considered carcinogenic. ${ }^{\mathbf{3 1 , 3 2}}$ Therefore, recognition and detection of BHA and BHT is important for public health and food safety.

We choose two free radical quencher type molecules specifically butylated hydroxyanisole (BHA) and 2,6-di-tert-butyl-4methylphenol (BHT) as template. Acrylamide (AM), 2-(dimethylamino) ethyl methacrylate (DMAEMA), FM3 and FM4 were used as functional monomers and ethylene glycol dimethacrylate (EGDMA) was chosen as cross-linker. The MIPs were

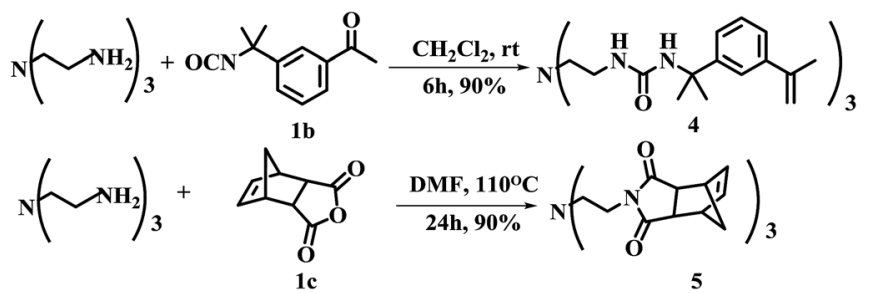

Scheme 1 Synthesis of three-armed functional monomer 4 and monomer 5 . prepared by both bulk polymerization and ring-opening metathesis polymerization. Details of synthetic procedures are summarized in the Table 3.

The preparation of MIPs and NIPs using traditional functional monomer, crosslinkers and the three-branched functional monomer bearing norbornene motif was investigated. In another words, the general procedure of free radical bulk polymerization and ring opening olefin metathesis polymerization were compared.

The free radical quencher type templates BHA and BHT were used as template for preparing MIPs with traditional free radical initiated bulk polymerization. As shown in Fig. 2A, the reaction for preparing $\mathrm{N} 1$ and $\mathrm{N} 2$ did not proceed well at RT. However, for $\mathrm{N} 1$ and $\mathrm{N} 2$, the polymerization was successful upon heating at $60{ }^{\circ} \mathrm{C}$ for $4 \mathrm{~h}$. For M1-1, M2-1, M1-2 and M2-2, polymerization was not observed both at room temperature and in water bath at $60{ }^{\circ} \mathrm{C}$ for $4 \mathrm{~h}$. However, in control experiments free-radical polymerization was successful in the absence of BHA and BHT in a water bath at $60{ }^{\circ} \mathrm{C}$ for $4 \mathrm{~h}$ (Fig. 2A1).

In contrast, free radical quencher type templates BHA and BHT were used as template for preparing MIPs with functional monomer 3 and 4 via ROMP (Fig. 2B and C). Results showed that polymerization of $\mathrm{N} 3$ and $\mathrm{N} 4$ using monomer 3 and 4 were successfully via ROMP in $5 \mathrm{~min}$ at room temperature (The polymerization of N4 occurred faster than N3). This could possibly due to the fact that FM4 have three double bonds. Furthermore, the preparation of MIPs with the monomer 3 and monomer 4 using BHT and BHA as template were successful. This was achieved using $2^{\text {nd }}$ generation Hoveyda-Grubbs catalyst via ROMP. The polymerization started after $10 \mathrm{~min}$ forming gel type polymer and was completed in 20 min even at room temperature. In conclusion, MIPs for BHT and BHA could be successfully prepared via ROMP with three armed norbornene based functional monomer using second generation HoveydaGrubbs catalyst via ROMP.

Binding capacity was measured by UV-Vis spectroscopy (see ESI Fig. S25-S28 $†$ ). The adsorption peak at $290 \mathrm{~nm}$ (BHA) and $280 \mathrm{~nm}$ (BHT) were chosen for the quantitative analysis. According to binding capacity and imprinting effect, the maximum adsorption capacity of FM3-BHA-MIP, FM3-BHA-NIP, FM3-BHT-MIP, FM3-BHT-NIP, FM4-BHA-MIP, FM4-BHA-NIP, FM4-BHT-MIP, FM4-BHT-NIP were $7.1 \mathrm{mg} \mathrm{g}^{-1}, 5.8 \mathrm{mg} \mathrm{g}^{-1}$, $5.3 \mathrm{mg} \mathrm{g}^{-1}, 3.6 \mathrm{mg} \mathrm{g}^{-1}, 12.2 \mathrm{mg} \mathrm{g}^{-1}, 8.7 \mathrm{mg} \mathrm{g}^{-1}, 11.3 \mathrm{mg} \mathrm{g}^{-1}$, $8.6 \mathrm{mg} \mathrm{g}^{-1}$, respectively. The higher binding capacity was attributed to specific binding sites in MIPs and thus higher affinity toward BHA/BHT than that of NIPs. Arco et al. ${ }^{32}$ reported BHA-imprinted polymer with the binding capacity of $6.08 \mathrm{mg}$ $\mathrm{g}^{-1}$ using 4-vinylpyridine (4-VP) and 1-viny-limidazole (1-VI) as the functional monomer. Because of the anti-oxidative nature of BHA and BHT, much more initiator had to be used with typical bulk polymerization.

\section{Experimental section}

\subsection{General method and materials}

General procedure. All reactions were monitored by TLC on silica gel plates visualized by UV lamp at $254 \mathrm{~nm}$. Nuclear 


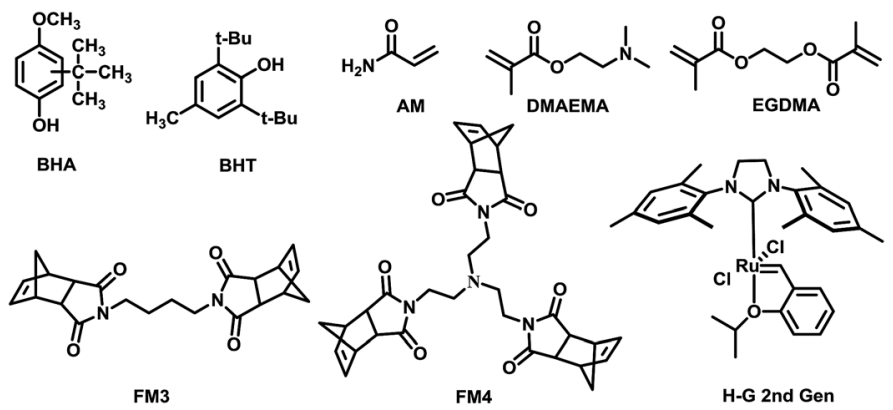

Fig. 1 Chemical structures of template, cross-linker, functional monomers and catalyst in polymers synthesis.

magnetic resonance (NMR) was measured on a VARIAN 400 spectrometer (Varian, Palo Alto, CA, USA) $\left({ }^{1} \mathrm{H}\right.$ NMR at $400 \mathrm{MHz}$ and ${ }^{13} \mathrm{C}$ NMR at $100 \mathrm{MHz}$ ). For ${ }^{1} \mathrm{H} \mathrm{NMR}, \mathrm{CDCl}_{3}$ at $7.26 \mathrm{ppm}$, $\mathrm{CD}_{3} \mathrm{OD}$ at $3.33 \mathrm{ppm}$ and $\mathrm{DMSO}-\mathrm{d}_{6}$ at $2.50 \mathrm{ppm}$ served as an internal standard, respectively. For ${ }^{13} \mathrm{C}$ NMR, $\mathrm{CDCl}_{3}$ at $77.16 \mathrm{ppm}, \mathrm{CD}_{3} \mathrm{OD}$ at $49.0 \mathrm{ppm}$ and $\mathrm{DMSO}_{6} \mathrm{~d}_{6}$ at $39.52 \mathrm{ppm}$ served as an internal standard, respectively. Multiplicity was reported using the following abbreviations: ( $\mathrm{s}=$ singlet, $\mathrm{d}=$ doublet, $\mathrm{t}=$ triplet, $\mathrm{q}=$ quartet, $\mathrm{m}=$ multiplet, $\mathrm{br}=$ broad). Mass spectra were measured on a QSTAR Elite (TOF) or a $4000 \mathrm{Q}$ TRAP in the ESI mode (AB SCIEX LLC, Redwood, CA, USA). The binding capacity of the MIPs and NIPs were measured by UV-Vis spectroscopy (UV-2600, Shimadzu, Kyoto, Japan).

Materials and reagents. All reagents and deuterated solvents were obtained commercially unless otherwise noted (All reagents were used as received). Starting material and HoveydaGrubbs catalyst $2^{\text {nd }}$ generation were purchased from Alfa-Aesar, Aldrich, Acros, Adamas and Ark pharm Reagent Co., Ltd. (Shanghai, China). Butylated hydroxyanisole (BHA), 2,6-di-tertbutyl-4-methylphenol (BHT), dimethylaminoethyl methacrylate
(DMAEMA), acrylamide (AM), ethylene glycol dimethacrylate (EGDMA), 1,1'-bi-2-naphthol and 2,2-azobis(isobutyronitrile) (AIBN) were purchased from Adamas Reagent Co., Ltd. (Shanghai, China).

\subsection{Synthetic procedure of functional monomers}

2-(3-(4-Aminobutyl)ureido)ethyl methacrylate (compound 2a). In a $100 \mathrm{~mL}$ flask, 1,4-diaminobutane ( $1 \mathrm{mmol}, 88 \mathrm{mg}$ ) was dissolved by $\mathrm{CH}_{3} \mathrm{CN}$ in an ice-water bath. 2-Isocyanatoethyl methacrylate ( $1 \mathrm{mmol}, 155 \mathrm{mg}$ ) were dissolved in $\mathrm{CH}_{3} \mathrm{CN}$ and cooled $30 \mathrm{~min}$, then it was dropwise slowly over $30 \mathrm{~min}$. The reaction mixture was stirring for $2 \mathrm{~h}$ at $0{ }^{\circ} \mathrm{C}$. The mixture was poured into ice-water $(25 \mathrm{~mL})$ and extracted with $\mathrm{CH}_{2} \mathrm{Cl}_{2}(3 \times 20$ $\mathrm{mL})$, the combined organic phase was washed with brine $(2 \times$ $20 \mathrm{~mL}$ ), dried over anhydrous $\mathrm{Na}_{2} \mathrm{SO}_{4}$ and concentrated under vacuum to give $166.2 \mathrm{mg}$ (68.4\%) of $2 \mathrm{a}$ as a yellow oil. ${ }^{1} \mathrm{H}$ NMR $\left(400 \mathrm{MHz}\right.$, methanol-d $\left._{4}\right) \delta 6.10(\mathrm{~s}, 1 \mathrm{H}), 5.61(\mathrm{~s}, 1 \mathrm{H}), 4.14(\mathrm{t}, J=$ $5.5 \mathrm{~Hz}, 2 \mathrm{H}), 3.40(\mathrm{t}, J=5.5 \mathrm{~Hz}, 2 \mathrm{H}), 3.30-3.27(\mathrm{~m}, 2 \mathrm{H}), 3.10(\mathrm{~s}$, 2H), $1.92(\mathrm{~s}, 3 \mathrm{H}), 1.46(\mathrm{~s}, 2 \mathrm{H}) .{ }^{13} \mathrm{C}$ NMR $\left(100 \mathrm{MHz}\right.$, methanol- $\left._{4}\right)$

Table 3 Polymerization conditions for the preparation of imprinted polymers 1-4 and non-imprinted polymers 1-4

\begin{tabular}{|c|c|c|c|c|c|}
\hline Polymer & Template (mmol) & $\mathrm{FM}(\mathrm{mmol})$ & Cross-linker (mmol) & Initiator (catalyst) & Solvent \\
\hline NIP & & 4 & 20 & $1 \mathrm{~mol} \%$ & $\mathrm{CH}_{2} \mathrm{Cl}_{2}$ \\
\hline MIP & 1 & 4 & 20 & $1 \mathrm{~mol} \%$ & $\mathrm{CH}_{2} \mathrm{Cl}_{2}$ \\
\hline Polymer $^{a, b}$ & $\begin{array}{l}\text { Template } \\
(\mathrm{mmol})\end{array}$ & FM (mmol) & Cross-linker (mmol) & Initiator (catalyst) & Solvent \\
\hline M1-2 & BHT (1) & $\mathrm{AM}(4)$ & EGDMA (20) & AIBN & $\mathrm{CH}_{2} \mathrm{Cl}_{2}$ \\
\hline N2 & & DMAEMA (4) & EGDMA (20) & AIBN & $\mathrm{CH}_{2} \mathrm{Cl}_{2}$ \\
\hline M2-1 & BHA (1) & DMAEMA (4) & EGDMA (20) & AIBN & $\mathrm{CH}_{2} \mathrm{Cl}_{2}$ \\
\hline M2-2 & BHT (1) & DMAEMA (4) & EGDMA (20) & AIBN & $\mathrm{CH}_{2} \mathrm{Cl}_{2}$ \\
\hline N3 & & FM3 (2.2) & & $2^{\text {nd }}$ gen $\mathrm{H}-\mathrm{G}$ & $\mathrm{CH}_{2} \mathrm{Cl}_{2}$ \\
\hline M3-1 & BHA (1) & FM3 (2.2) & & $2^{\text {nd }}$ gen $\mathrm{H}-\mathrm{G}$ & $\mathrm{CH}_{2} \mathrm{Cl}_{2}$ \\
\hline
\end{tabular}

${ }^{a}$ Bulk polymerization (N1, M1-1, M1-2, N2, M2-1, M2-2). ${ }^{b}$ Ring-opening metathesis polymerization (N3, M3-1, M3-2, N4, M4-1, M4-2). 


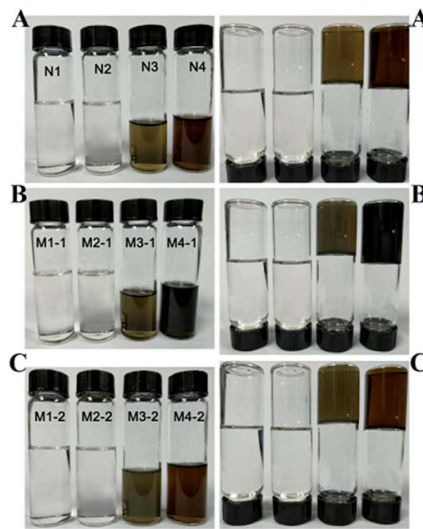

Polymerization 20min at RT

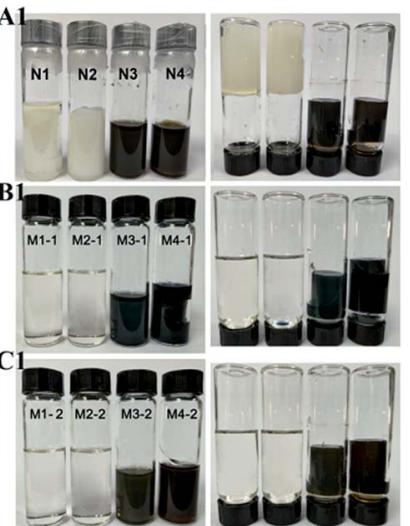

Polymerization $4 \mathrm{~h}$ at $60^{\circ} \mathrm{C}$
Fig. 2 Comparation of the bulk polymerization and ring-opening metathesis polymerization. N1(NIP): $A M$ and EGDMA with AIBN; N2(NIP): DMAEMA and EGDMA with AIBN; N3(NIP): FM3 with $2^{\text {nd }}$ Hoveyda-Grubbs catalyst; N4(NIP): FM4 with $2^{\text {nd }}$ Hoveyda-Grubbs catalyst. $\mathrm{M}-1(\mathrm{MIP})$ : $\mathrm{BHA}$ as template; $\mathrm{M}-2(\mathrm{MIP})$ : $\mathrm{BHT}$ as template. (N/M 1 and N/M 2): bulk polymerization; (N/M 3 and N/M 4) ring-opening metathesis polymerization.

$\delta$ 136.22, 124.91, 124.86, 63.83, 39.23, 38.54, 27.18, 16.98. MSESI $(m / z) \mathrm{C}_{11} \mathrm{H}_{21} \mathrm{~N}_{3} \mathrm{O} 3\left([\mathrm{M}+\mathrm{H}]^{-}\right): 242.2$.

1-(4-Aminobutyl)-3-(2-(3-(prop-1-en-2-yl)phenyl)propan-2-yl) urea (compound 2 b). In a $100 \mathrm{~mL}$ flask, 1,4-diaminobutane ( $1 \mathrm{mmol}, 88 \mathrm{mg}$ ) were dissolved by dry $\mathrm{CH}_{2} \mathrm{Cl}_{2}$ in an ice-water bath. 3-Isopropenyl- $\alpha, \alpha$-dimethylbenzyl isocyanate $(1 \mathrm{mmol}$, $201 \mathrm{mg}$ ) were dissolved in dry $\mathrm{CH}_{2} \mathrm{Cl}_{2}$ and cooled $30 \mathrm{~min}$, then it was dropwise slowly over $30 \mathrm{~min}$. The mixture was poured into ice-water $(25 \mathrm{~mL})$ and extracted with $\mathrm{CH}_{2} \mathrm{Cl}_{2}(3 \times 20 \mathrm{~mL})$, the combined organic phase was washed with saturated salt water $(2 \times 20 \mathrm{~mL})$, dried over anhydrous $\mathrm{Na}_{2} \mathrm{SO}_{4}$ and concentrated in vacuo to give $227.7 \mathrm{mg}(78.8 \%)$ of $2 \mathbf{b}$ as a white solid. ${ }^{1} \mathrm{H}$ NMR $\left(400 \mathrm{MHz}, \mathrm{CDCl}_{3}\right) \delta 7.58(\mathrm{~s}, 1 \mathrm{H}), 7.43-7.28(\mathrm{~m}, 3 \mathrm{H}), 5.37(\mathrm{~s}, 1 \mathrm{H})$, $5.09(\mathrm{~d}, J=11.3 \mathrm{~Hz}, 1 \mathrm{H}), 4.83(\mathrm{~s}, 1 \mathrm{H}), 3.48(\mathrm{~s}, 1 \mathrm{H}), 3.05(\mathrm{t}, J=$ $6.6 \mathrm{~Hz}, 2 \mathrm{H}), 2.56(\mathrm{t}, J=6.7 \mathrm{~Hz}, 2 \mathrm{H}), 2.16(\mathrm{~s}, 3 \mathrm{H}), 1.63(\mathrm{~d}, J=$ $8.3 \mathrm{~Hz}, 6 \mathrm{H}), 1.58(\mathrm{~s}, 2 \mathrm{H}), 1.32-1.14(\mathrm{~m}, 4 \mathrm{H}) .{ }^{13} \mathrm{C} \mathrm{NMR}(100 \mathrm{MHz}$, $\left.\mathrm{CDCl}_{3}\right) \delta 157.60(\mathrm{~s}), 143.34(\mathrm{~s}), 141.60$ (s), $128.24(\mathrm{~s}), 124.32$ (s), 124.11 (s), 122.66-122.46 (m), 112.73 (s), 54.75 (s), 39.60 (s), 30.61 (s), 30.41 (s), 29.42 (s), 27.39 (s), 22.10 (s). MS-ESI ( $\mathrm{m} / \mathrm{z})$ $\mathrm{C}_{17} \mathrm{H}_{27} \mathrm{~N}_{3} \mathrm{O}\left([\mathrm{M}+\mathrm{H}]^{-}\right)$: 288.5 .

4,11-Dioxo-3,5,10,12-tetraazatetradecane-1,14-diyl bis(2methyl-acrylate) (compound $2 \mathrm{c}$ was synthesized according to similar procedures ${ }^{22,23}$ ). In a $100 \mathrm{~mL}$ flask, 1,4-diaminobutane ( $1 \mathrm{mmol}, 88 \mathrm{mg}$ ) were dissolved by $\mathrm{CH}_{3} \mathrm{CN}$ in an ice-water bath. 2-Isocyanatoethyl methacrylate $(2.1 \mathrm{mmol}, 325 \mathrm{mg})$ was dissolved in $\mathrm{CH}_{2} \mathrm{Cl}_{2}$ and cooled $30 \mathrm{~min}$, and then it was dropwise slowly over $30 \mathrm{~min}$. The reaction mixture was allowed to warm room temperature and stirring for $2 \mathrm{~h}$. The mixture was filtered and washed with $\mathrm{CH}_{2} \mathrm{Cl}_{2}$, the white powder was dried for $8 \mathrm{~h}$ at $50{ }^{\circ} \mathrm{C}$ under reduced pressure (397.2 mg, 99.8\%). ${ }^{1} \mathrm{H}$ NMR (400 MHz, DMSO-d $\left.{ }_{6}\right) \delta$ H $6.05(1 \mathrm{H}, \mathrm{s}), 5.91(2 \mathrm{H}, \mathrm{s}), 5.68(1 \mathrm{H}, \mathrm{s}), 4.04$ $(2 \mathrm{H}, \mathrm{t}, J=5.6 \mathrm{~Hz}), 3.30(1 \mathrm{H}, \mathrm{d}, J=10.0 \mathrm{~Hz}), 3.27(2 \mathrm{H}, \mathrm{dd}, J=$ $11.4 \mathrm{~Hz}, J=5.7 \mathrm{~Hz}), 2.96(2 \mathrm{H}, \mathrm{d}, J=3.2 \mathrm{~Hz}), 1.88(3 \mathrm{H}, \mathrm{s}), 1.32$ $(2 \mathrm{H}, \mathrm{s}) .{ }^{13} \mathrm{C}$ NMR (100 MHz, DMSO-d 6 ) $\delta 166.94(\mathrm{~s}), 158.35$ (s),
136.28 (s), 126.23 (s), 64.57 (s), 39.48 (s), 38.67 (s), 27.93 (s), 18.41 (s). HRMS-ESI $(\mathrm{m} / \mathrm{z}) \mathrm{C}_{30} \mathrm{H}_{42} \mathrm{~N}_{4} \mathrm{O}_{2}\left([\mathrm{M}+\mathrm{H}]^{-}\right): 399.2389$.

1,1'-(Butane-1,4-diyl)bis(3-(2-(3-(prop-1-en-2-yl)phenyl)propan2-yl)urea) (compound $2 \mathrm{~d}$ was synthesized according to similar procedures $^{22}$ ). In a $100 \mathrm{~mL}$ flask, 1,4-diaminobutane ( $1 \mathrm{mmol}, 88$ $\mathrm{mg}$ ) were dissolved by dry $\mathrm{CH}_{2} \mathrm{Cl}_{2}$ in an ice-water bath. 3-Isopropenyl- $\alpha, \alpha$-dimethylbenzyl isocyanate $(2.1 \mathrm{mmol}, 422 \mathrm{mg})$ were dissolved in dry $\mathrm{CH}_{3} \mathrm{CN}$ and cooled $30 \mathrm{~min}$, then it was dropwise slowly over $30 \mathrm{~min}$. The reaction mixture was allowed to warm room temperature and stirring for $2 \mathrm{~h}$. The mixture was filtered and washed with $\mathrm{CH}_{2} \mathrm{Cl}_{2}$, the white powder was dried for $8 \mathrm{~h}$ at $50{ }^{\circ} \mathrm{C}$ under reduced pressure (473.8 mg, 96.7\%). ${ }^{1} \mathrm{H}$ NMR (400 $\mathrm{MHz}, \mathrm{DMSO}) \delta_{\mathrm{H}} 7.41(2 \mathrm{H}, \mathrm{s}), 7.24(6 \mathrm{H}, \mathrm{dd}, J=11.1, J=4.1), 6.17$ $(2 \mathrm{H}, \mathrm{s}), 5.75(2 \mathrm{H}, \mathrm{t}, J=5.6), 5.33(2 \mathrm{H}, \mathrm{s}), 5.04(2 \mathrm{H}, \mathrm{s}), 2.86(4 \mathrm{H}, \mathrm{d}, J=$ 5.1), 2.07 (6H, s), $1.50(12 \mathrm{H}, \mathrm{s}), 1.27$ (4H, s). ${ }^{13} \mathrm{C}$ NMR (100 MHz, DMSO-d $\left._{6}\right) \delta 157.51(\mathrm{~s}), 149.58(\mathrm{~s}), 143.49(\mathrm{~s}), 140.01(\mathrm{~s}), 128.24(\mathrm{~s})$, 124.66 (s), 123.16 (s), 122.12 (s), 112.63 (s), 54.48 (s), 30.58 (s), 28.05 (s), 22.01 (s). MS-ESI $(\mathrm{m} / \mathrm{z}) \mathrm{C}_{30} \mathrm{H}_{42} \mathrm{~N}_{4} \mathrm{O}_{2}\left([\mathrm{M}-\mathrm{H}]^{-}\right): 489.8$.

2-(3-(6-Methyl-4-oxo-1,4-dihydropyrimidin-2-yl)ureido)ethyl methacrylate (compound 3a). To a stirred solution of 2-amino4-hydroxy-6-methylpyrimidine (1 mmol, $125 \mathrm{mg}$ ) and 2-isocyanatoethyl methacrylate ( $3 \mathrm{mmol}, 465 \mathrm{mg}$ ) in $6 \mathrm{~mL}$ pyridine. The reaction was heated to $100{ }^{\circ} \mathrm{C}$ and stirred for $8 \mathrm{~h}$. The reaction mixture cooled to room temperature and the resulting solid was filtered and washed with acetone. The crude product was recrystallized with chloroform: acetone $(1: 1)$, the white solid was dried at $50{ }^{\circ} \mathrm{C}$ under reduced pressure $(234.9 \mathrm{mg}$, 83.9\%). ${ }^{1} \mathrm{H} \mathrm{NMR}\left(400 \mathrm{MHz}, \mathrm{CDCl}_{3}\right) \delta 12.97(\mathrm{~s}, 1 \mathrm{H}), 11.92(\mathrm{~s}, 1 \mathrm{H})$, 10.48 (s, 1H), 6.18 (s, 1H), $5.78(\mathrm{~s}, 1 \mathrm{H}), 5.55(\mathrm{~s}, 1 \mathrm{H}), 4.27(\mathrm{~s}, 2 \mathrm{H})$, $3.59(\mathrm{~s}, 2 \mathrm{H}), 2.20(\mathrm{~d}, J=26.8 \mathrm{~Hz}, 3 \mathrm{H}), 1.94(\mathrm{~s}, 3 \mathrm{H}) .{ }^{13} \mathrm{C}$ NMR $(100$ $\left.\mathrm{MHz}, \mathrm{CDCl}_{3}\right) \delta 172.58(\mathrm{~s}), 167.30(\mathrm{~s}), 156.79(\mathrm{~s}), 154.92(\mathrm{~s}), 148.25$ (s), 136.07 (s), 125.78 (s), 106.49 (s), 63.09 (s), 38.80 (s), 19.16 (s), 18.30 (s). MS-ESI $(m / z) \mathrm{C}_{12} \mathrm{H}_{16} \mathrm{~N}_{4} \mathrm{O}_{4}\left([\mathrm{M}-\mathrm{H}]^{-}\right)$: 279.2.

1-(6-Methyl-4-oxo-1,4-dihydropyrimidin-2-yl)-3-(2-(3-(prop-1en-2-yl)phenyl)propan-2-yl)urea (compound $3 \mathrm{~b}$ ). To a stirred solution of 2-amino-4-hydroxy-6-methylpyrimidine $(1 \mathrm{mmol}$, $125 \mathrm{mg}$ ) and 3-isopropenyl- $\alpha, \alpha$-dimethylbenzyl isocyanate $(1.3 \mathrm{mmol}, 261 \mathrm{mg})$ in $6 \mathrm{~mL}$ DMSO. The reaction was heated to $170{ }^{\circ} \mathrm{C}$ and stirred for $5 \mathrm{~min}$. The reaction mixture cooled to room temperature and poured into ice-water $(10 \mathrm{~mL})$ and the resulting precipitate was filtered and washed with $\mathrm{CH}_{2} \mathrm{Cl}_{2}$, the white powder was dried for $8 \mathrm{~h}$ at $50{ }^{\circ} \mathrm{C}$ under reduced pressure (292.1 mg, 89.6\%). ${ }^{1} \mathrm{H}$ NMR (400 MHz, $\mathrm{CDCl}_{3}$ ) $\delta 12.87(\mathrm{~s}, 1 \mathrm{H})$, 11.97 (s, 1H), $10.31(\mathrm{~s}, 1 \mathrm{H}), 7.53(\mathrm{~s}, 1 \mathrm{H}), 7.38-7.26(\mathrm{~m}, 3 \mathrm{H}), 5.81$ $(\mathrm{s}, 1 \mathrm{H}), 5.36(\mathrm{~s}, 1 \mathrm{H}), 5.07(\mathrm{~s}, 1 \mathrm{H}), 2.14(\mathrm{~d}, J=9.8 \mathrm{~Hz}, 6 \mathrm{H}), 1.75(\mathrm{~s}$, 6H). ${ }^{13} \mathrm{C} \mathrm{NMR}\left(100 \mathrm{MHz}, \mathrm{CDCl}_{3}\right) \delta 172.79(\mathrm{~s}), 155.49(\mathrm{~s}), 154.83$ (s), 148.11 (s), 147.67 (s), 143.54 (s), 141.13 (s), 128.11 (s), 123.73 $(\mathrm{d}, J=18.4 \mathrm{~Hz}), 121.83(\mathrm{~s}), 112.37(\mathrm{~s}), 106.84(\mathrm{~s}), 55.76(\mathrm{~s}), 29.73$ (s), 22.09-21.80 (m), $18.96(\mathrm{~s})$. MS-ESI $(\mathrm{m} / \mathrm{z}) \mathrm{C}_{18} \mathrm{H}_{22} \mathrm{~N}_{4} \mathrm{O}_{2}([\mathrm{M}-$ $\left.\mathrm{H}]^{-}\right)$: 325.6.

1,1', $\mathbf{1}^{\prime \prime}$-(Nitrilotris(ethane-2,1-diyl))tris(3-(2-(3-(prop-1-en-2-1) phenyl)propan-2-yl)urea) (compound 4 was synthesized according to similar procedures ${ }^{22}$ ). In a $100 \mathrm{~mL}$ flask, tris(2aminoethyl)amine (1 mmol, $146 \mathrm{mg}$ ) were dissolved in dry $\mathrm{CH}_{2} \mathrm{Cl}_{2}$. 3-Isopropenyl- $\alpha, \alpha$-dimethylbenzyl isocyanate (2.1 mmol, $422 \mathrm{mg}$ ) were dissolved in dry $\mathrm{CH}_{2} \mathrm{Cl}_{2}$, then it was dropwise slowly over $30 \mathrm{~min}$. The reaction was stirring for $6 \mathrm{~h}$ in 
room temperature. The mixture was filtered and washed with $\mathrm{CH}_{2} \mathrm{Cl}_{2}$, the white powder was dried for $8 \mathrm{~h}$ at $40{ }^{\circ} \mathrm{C}$ under reduced pressure (678.0 mg, 90.4\%). ${ }^{1} \mathrm{H} \mathrm{NMR}\left(400 \mathrm{MHz}, \mathrm{CDCl}_{3}\right.$ ) $\delta_{\mathrm{H}} 7.44(3 \mathrm{H}, \mathrm{s}), 7.30-7.15(9 \mathrm{H}, \mathrm{m}), 5.88(6 \mathrm{H}, \mathrm{s}), 5.30(3 \mathrm{H}, \mathrm{s}), 5.02$ $(3 \mathrm{H}, \mathrm{s}), 2.98$ (6H, s), $2.29(6 \mathrm{H}, \mathrm{s}), 2.09(9 \mathrm{H}, \mathrm{s}), 1.52(18 \mathrm{H}, \mathrm{s}) \cdot{ }^{13} \mathrm{C}$ NMR (100 MHz, $\mathrm{CDCl}_{3}$ ) $\delta 158.30(\mathrm{~s}), 148.26(\mathrm{~s}), 143.43(\mathrm{~s}), 140.93$ (s), 128.02 (s), 124.16 (s), 123.43 (s), 121.84 (s), 112.25 (s), 109.89 $(\mathrm{s}), 55.61(\mathrm{~s}), 54.76(\mathrm{~s}), 38.24(\mathrm{~s}), 30.32(\mathrm{~s}), 22.03(\mathrm{~s})$. MS-ESI $(\mathrm{m} / \mathrm{z})$ $\mathrm{C}_{45} \mathrm{H}_{63} \mathrm{~N}_{7} \mathrm{O}_{3}\left([\mathrm{M}]^{-}\right): 750.5$.

$\left(3 a R, 3 a^{\prime} R, 7 a S, 7 a^{\prime} S\right)-2,2^{\prime}-(((2-((3 a R, 4 S, 7 R, 7 a S)-1,3-D i o x o-$ 1,3,3a,4,7,7a-hexahydro-2H-4,7-methanoisoindol-2-yl)ethyl) azanediyl)bis(ethane-2,1-diyl))bis(3a,4,7,7a-tetrahydro- $1 H$ 4,7-methanoiso-indole-1,3(2H)-dione) (compound 5 was synthesized according to similar procedures $\left.{ }^{25}\right)$. Tris(2aminoethyl)amine ( $1 \mathrm{mmol}, 146 \mathrm{mg}$ ) and cis-5-norborneneendo-2,3-dicarboxylic anhydride $(3.1 \mathrm{mmol}, 508 \mathrm{mg})$ were dissolved in $5 \mathrm{~mL}$ of DMF and heated to $110{ }^{\circ} \mathrm{C}$ for 24 hours. The reaction mixture was cooled to temperature and ice cold water was added. A white solid was obtained by suction filtration, washed with ice cold water and dried at $60^{\circ} \mathrm{C}$ under reduced pressure (525.6 mg, 90.0\%). ${ }^{1} \mathrm{H}$ NMR $(400 \mathrm{MHz}$, $\left.\mathrm{CDCl}_{3}\right) \delta 6.06(\mathrm{~s}, 6 \mathrm{H}), 3.41-3.21(\mathrm{~m}, 18 \mathrm{H}), 2.49(\mathrm{~s}, 6 \mathrm{H}), 1.69(\mathrm{~d}$, $J=8.6 \mathrm{~Hz}, 3 \mathrm{H}), 1.52(\mathrm{~d}, J=8.6 \mathrm{~Hz}, 3 \mathrm{H}) .{ }^{13} \mathrm{C} \mathrm{NMR}(100 \mathrm{MHz}$, $\left.\mathrm{CDCl}_{3}\right) \delta 177.56(\mathrm{~s}), 134.39(\mathrm{~s}), 51.96(\mathrm{~s}), 50.87$ (s), $45.86(\mathrm{~s})$, 44.43 (s), $35.80(\mathrm{~s})$. HRMS-ESI $(\mathrm{m} / \mathrm{z}) \mathrm{C}_{33} \mathrm{H}_{36} \mathrm{~N}_{4} \mathrm{O}_{6}\left([\mathrm{M}+\mathrm{H}]^{-}\right)$: 585.2376.

$\left(3 a R, 3 a^{\prime} R, 4 S, 4^{\prime} S, 7 R, 7 a S, 7^{\prime} R, 7 a^{\prime} S\right)-2,2^{\prime}$-(Butane-1,4-diyl) bis $(3 a, 4,7,7 a$-tetrahydro-1 $H$-4,7-methanoisoindole-1,3(2H)dione) (FM3 was prepared according was synthesized according to a published procedure ${ }^{25}$ ). 1,4-diaminobutane (1 mmol, $88 \mathrm{mg}$ ) and cis-5-norbornene-endo-2,3-dicarboxylic anhydride (2.1 mmol, $344 \mathrm{mg}$ ) were dissolved in $5 \mathrm{~mL}$ of DMF and heated to $110^{\circ} \mathrm{C}$ for 24 hours. The reaction mixture was cooled to temperature and ice cold water was added. A white solid was obtained by suction filtration, washed with ice cold water and dried at $60{ }^{\circ} \mathrm{C}$ under reduced pressure (316.2 mg, 83.2\%). ${ }^{1} \mathrm{H}$ NMR $\left(400 \mathrm{MHz}, \mathrm{CDCl}_{3}\right) \delta 6.06(\mathrm{~s}, 4 \mathrm{H})$, $3.34(\mathrm{~s}, 4 \mathrm{H}), 3.26(\mathrm{~s}, 4 \mathrm{H}), 3.19(\mathrm{~s}, 4 \mathrm{H}), 1.69(\mathrm{~d}, J=8.7 \mathrm{~Hz}, 2 \mathrm{H})$, $1.50(\mathrm{~d}, J=8.7 \mathrm{~Hz}, 2 \mathrm{H}), 1.35(\mathrm{~s}, 4 \mathrm{H}) .{ }^{13} \mathrm{C} \mathrm{NMR}(100 \mathrm{MHz}$, $\left.\mathrm{CDCl}_{3}\right) \delta 177.57(\mathrm{~s}), 134.53-134.23(\mathrm{~m}), 52.18(\mathrm{~s}), 45.83-$ $45.36(\mathrm{~m}), 44.97-44.68(\mathrm{~m}), 37.64(\mathrm{~s}), 25.05(\mathrm{~s})$.

\subsection{Synthesis of BHA/BHT-MIPs and NIPs}

General procedure of bulk polymerization. Template (1 mmol), functional monomer ( $4 \mathrm{mmol})$, EGDMA (20 mmol) and AIBN (1 mol\%) were dissolved in $4 \mathrm{~mL}$ dichloromethane in a screw-capped vial. This mixture was sonicated for $5 \mathrm{~min}$ and degassed for 15 min under nitrogen. The polymerization was continued for an additional $20 \mathrm{~min}$ at room temperature. The vial was heated in a water bath at $60^{\circ} \mathrm{C}$ for $4 \mathrm{~h}$. As a blank, a nonimprinted polymer (NIP) was synthesized following the same protocol but without template. ${ }^{28}$

General procedure of ring-opening metathesis polymerization. Template $(1 \mathrm{mmol})$ and functional monomer $(1.3 / 2.2$ $\mathrm{mmol}$ ) were dissolved in dichloromethane $(4 \mathrm{~mL})$ in a $10 \mathrm{~mL}$ screw-capped vial. Second generation Hoveyda-Grubbs catalyst
( $1 \mathrm{~mol} \%$ ) was added to the reaction mixture and the reaction mixture was briefly shaken. After $5 \mathrm{~min}$, the reaction mixture began to turn cloudy. The polymerization was continued for an additional $20 \mathrm{~min}$ at room temperature. Then the reaction vial was heated in water bath at $60{ }^{\circ} \mathrm{C}$ for 4 hours. As a blank, a nonimprinted control polymer (NIP) was synthesized following the same protocol but without template..$^{25,28}$

\subsection{Adsorption kinetic experiments}

BHA/BHT-MIPs (7 samples, $10 \mathrm{mg}$ each) and NIPs (7 samples, $10 \mathrm{mg}$ each) samples were added to $5 \mathrm{~mL}$ of $50 \mathrm{mg} \mathrm{L}^{-1}$ / $100 \mathrm{mg} \mathrm{L}{ }^{-1}$ BHA/BHT- $\mathrm{CH}_{3} \mathrm{OH}$ solution. The mixtures were incubated in a shaker and were sampled at time-intervals of $240 \mathrm{~min}, 360 \mathrm{~min}, 480 \mathrm{~min}, 720 \mathrm{~min}, 840 \mathrm{~min}, 960 \mathrm{~min}$, and $1080 \mathrm{~min}$. Each time sample was passed through a filter $0.2 \mu \mathrm{m}$ PTFE syringe filters) to separate particles from supernatant. Residual concentrations of $\mathrm{BHA} / \mathrm{BHT}$ in filtrate were quantified by measuring the UV absorbance at $290 / 280 \mathrm{~nm}$. The adsorption capacity can be calculated according to the following equation (eqn (1)):

$$
Q_{\mathrm{t}}=\frac{\left(C_{0}-C_{\mathrm{t}}\right) V}{m}
$$

where $Q_{\mathrm{t}}\left(\mathrm{mg} \mathrm{g}^{-1}\right)$ is adsorption capacity of MIPs and NIPs at different time-intervals, $C_{0}\left(\mathrm{mg} \mathrm{L}^{-1}\right)$ and $C_{\mathrm{t}}\left(\mathrm{mg} \mathrm{L}^{-1}\right)$ are the initial and residual concentrations of $\mathrm{BHA} / \mathrm{BHT}$ respectively, $V$ $(\mathrm{L})$ is the volume of BHA/BHT solution, and $m(\mathrm{~g})$ is the mass of the absorbent.

\section{Conclusions}

In summary, functional monomers bearing urea, supramolecular UPy motif and three-branched nitrogen centered norbornene motif were designed and synthesized with decent to excellent yields. The approach featured several advantages such as short reaction times, mild reaction conditions and no need for column chromatographic purification. The norbornene based FM was used for preparing molecularly imprinted polymers (MIPs) via Ring-Opening Metathesis Polymerization (ROMP). Results showed that norbornene based three-branched functional monomers could be used for preparing MIPs for free radical quencher type template molecules. Further optimization and applications of these functional monomers for advanced functional materials design and molecularly imprinted polymers are in progress.

\section{Conflicts of interest}

There are no conflicts of interest to declare.

\section{Acknowledgements}

This work was financially supported by National Natural Science Foundation of China $(21464015,21472235)$, Xinjiang Tianshan Talents Program (2018xgytsyc2-3), “One Thousand Talents” Program of China (Y32H291501), Young Elite Scientist Sponsorship Program by CAST (2017QNRC001), and the West 
Light Foundation of the Chinese Academy of Sciences, Grant No. 2017-XBQNXZ-B-001.

\section{Notes and references}

1 G. Wuff and A. Sarhan, Angew. Chem., Int. Ed., 1972, 11, 341345.

2 R. Arshady and K. Mosbach, Macromol. Chem. Phys., 1981, 182, 687-692.

3 J. D. Lee, N. T. Greene, G. T. Rushton, K. D. Shimizu and J. I. Hong, Org. Lett., 2005, 7, 963-966.

4 G. Vlatakis, L. I. Andersson, R. Müller and K. Mosbach, Nature, 1993, 361, 645-647.

5 R. L. Adkins, N. Walsh, M. Edmunds and J. M. Trafford, Analyst, 1995, 120, 1433-1436.

6 L. Chen, S. Xu and J. Li, Chem. Soc. Rev., 2011, 40, 2922-2942.

7 Y. G. Zhang, D. Song, L. M. Lanni and K. D. Shimizu, Macromolecules, 2010, 43, 6284-6294.

8 Y. Zhang, D. Song, J. C. Brown and K. D. Shimizu, Org. Biomol. Chem., 2011, 9, 120-126.

9 L. S. Shimizu, A. D. Hughes, M. D. Smith, M. J. Davis, B. P. Zhang, H. C. zur Loye and K. D. Shimizu, J. Am. Chem. Soc., 2003, 125, 14972-14973.

10 C. R. Bowers, M. Dvoyashkin, S. R. Salpage, C. Akel, H. Bhase, M. F. Geer and L. S. Shimizu, ACS Nano, 2015, 9, 6343-6353.

11 L. S. Shimizu, S. R. Salpage and A. A. Korous, Acc. Chem. Res., 2014, 47, 2116-2127.

12 J. Yang, M. B. Dewal and L. S. Shimizu, J. Am. Chem. Soc., 2006, 128, 8122-8123.

13 J. Yang, M. B. Dewal, S. Profeta, M. D. Smith, Y. Li and L. S. Shimizu, J. Am. Chem. Soc., 2008, 130, 612-621.

14 S. Dawn, M. B. Dewal, D. Sobransingh, M. C. Paderes, A. C. Wibowo, M. D. Smith, J. A. Krause, P. J. Pellechia and L. S. Shimize, J. Am. Chem. Soc., 2011, 133, 7025-7032.

15 Y. Yu, Q. Zhang, J. Buscaglia, C.-C. Chang, Y. Liu, Z. Yang, Y. Guo, Y. Wang, K. Levon and M. Rafailovich, Analyst, 2016, 141, 4424-4431.
16 Y. Yu, Q. Zhang, C.-C. Chang, Y. Liu, Z. Yang, Y. Guo, Y. Wang, D. K. Galanakis, K. Levon and M. Rafailovich, Analyst, 2016, 141, 5607-5617.

17 C. Gomy and A. R. Schmitzer, J. Org. Chem., 2006, 71, 31213125.

18 R. P. Sijbesma, F. H. Beijer, L. Brunsveld, B. J. B. Folmer, J. Hirschberg, R. F. M. Lange, J. K. L. Lowe and E. W. Meijer, Science, 1997, 278, 1601-1604.

19 F. H. Beijer, R. P. Sijbesma, H. Kooijman, A. L. Spek and E. W. Meijer, J. Am. Chem. Soc., 1998, 120, 6761-6769.

20 S. H. M. Sontjens, R. P. Sijbesma, M. H. P. van Genderen and E. W. Meijer, J. Am. Chem. Soc., 2000, 122, 7487-7493.

21 Y. G. Zhang and K. D. Shimizu, Abstracts of Papers of the American Chemical Society, 2007, 233.

22 D. Song, Y. G. Zhang, M. F. Geer and K. D. Shimizu, J. Mol. Recognit., 2014, 27, 448-457.

23 X. G. Wu, K. Goswami and K. D. Shimizu, J. Mol. Recognit., 2008, 21, 410-418.

24 R. Wagner, W. Wan, M. Biyikal, E. Benito-Pena, M. C. Moreno-Bondi, I. Lazraq, K. Rurack and B. Sellergren, J. Org. Chem., 2013, 78, 1377-1389.

25 Y. G. Zhang, J. M. Lavin and K. D. Shimizu, J. Am. Chem. Soc., 2009, 131, 12062-12063.

26 L. Chen, X. Wang, W. Lu, X. Wu and J. Li, Chem. Soc. Rev., 2016, 45, 2137.

27 H. Y. Yan and K. H. Row, Int. J. Mol. Sci., 2006, 7, 155-178.

28 K. Zhi, L. Wang, Y. Zhang, X. Zhang, L. Zhang, L. Liu, J. Yao and W. Xiang, J. Mol. Recognit., 2017, e2627.

29 S. Kanaoka and R. H. Grubbs, Macromolecules, 1995, 28, 4707-4713.

30 K. H. Yoon, K. O. Kim, C. Q. Wang, I. Park and D. Y. Yoon, J. Polym. Sci., Part A: Polym. Chem., 2012, 50, 3914-3921.

31 G. M. Williams, M. J. Iatropoulos and J. Whysner, Food Chem. Toxicol., 1999, 37, 1027-1038.

32 L. L. Vallo, R. T. Laxamana, F. U. Paredes, I. H. J. Arellano and S. D. Arco, Mater. Lett., 2015, 159, 317-320. 